THE ECONOMICS OF CHOICE BETWEEN ENERGY

SOURCES 
Also edited by Douglas Hague:

ECONOMIC PROGRESS (with Léon Dupriez)

THE ECONOMICS OF RELATIVE PRICES

(with Béla Csikós-Nagy and Graham Hall)

STRUCTURAL ADJUSTMENT IN DEVELOPED OPEN

ECONOMIES (with Karl Jungenfelt)

Also edited by Chris Rowland:

THE ECONOMICS OF NORTH SEA OIL TAXATION

(with Danny Hann) 


\section{The Economics of Choice between Energy Sources}

Proceedings of a Conference held by the International Economic Association in

Tokyo, Japan

Edited by

Pierre Maillet,

Douglas Hague

and

Chris Rowland 
ISBN 978-1-349-18626-6 ISBN 978-1-349-18624-2 (eBook)

DOI 10.1007/978-1-349-18624-2

(C) International Economic Association, 1987

Softcover reprint of the hardcover 1st edition 1987

All rights reserved. For information, write:

Scholarly \& Reference Division,

St. Martin's Press, Inc., 175 Fifth Avenue, New York, NY 10010

First published in the United States of America in 1987

ISBN 978-0-312-23677-9

Library of Congress Cataloging-in-Publication Data The Economics of choice between energy sources. Includes index.

1. Energy policy-Congresses. I. Maillet, Pierre, professeur de science économique. II. Hague, Douglas

Chalmers. III. Rowland, Chris. IV. International

Economic Association.

HD9502.A2E24 $1987 \quad 333.79 \quad 86-13732$

ISBN 978-0-312-23677-9 


\section{Contents}

Foreword Pierre Maillet ix

Acknowledgements $\quad$ xi

List of Contributors and Participants xiii

Abbreviations and Acronyms $\quad \mathrm{Xv}$

1 Presentation of the Conference Pierre Maillet 1

PART ONE: METHODOLOGY

2 Energy Options: Interface Connections Between the Energy Sphere and the Rest of the Economy Pierre Maillet $\quad 19$

Comment: Wolfgang Sassin 45

3 Fossil Energy and its Alternatives: a Problem Beyond Costs and Prices Wolfgang Sassin 51

4 Problems Concerning the Implementation of Energy Policies Michael Posner $\quad 76$

5 The Implementation of Energy Policy Goals Hans-Karl Schneider and Walter Schulz 93

Summary of the Discussion on Methodology 112

PART TWO: THE ENERGY BACKGROUND

6 The Need for all Available Sources of Energy Joe Stanislaw

7 Economic Factors Affecting the Development of Alternative Energy Sources Giorgio Szegö 
8 The 'Invisible' Source of Alternative Energy: a

Comparison of Energy Conservation Performance

in East and West Istvan Dobozi

9 Oil-price Increases and Macroeconomic Instability:

General equilibrium Calculations on the Basis of

Swedish Data Lars Bergman

208

Summary of the Discussion on the Energy Background

226

\section{PART THREE: POLICY CHOICES IN DEVELOPED COUNTRIES}

10 Reflections on Energy Planning in France Lucien Gouni

11 Alternative Sources of Energy in the National Economy of the Soviet Union $V$. A. Shelest

12 Lignite - a Domestic Resource in the GDR's Energy Policy: Macroeconomic Problems Gerhard Hüber

13 Policy Choices in Developed Countries: Two Japanese Views
A. N. Amaya
B. Toyoaki Ikutu

Summary of the Discussion on Energy Choices in Developed Countries

PART FOUR: POLICY CHOICES IN DEVELOPING COUNTRIES

$$
\text { A Latin America }
$$

14 Brazilian Energy Policy at a Crossroad Antonio Barros de Castro

15 The Economics of Alternative Sources of Energy: a View from Venezuela José M. Uzcategui

16 Energy Planning and Oil in Mexico: the Outstanding Issues in Historical perspective Miguel Wionczek 
17 Energy Development Choices for India Kamta Prasad and S. Ramesh

18 Planning for Alternative Energy Sources - Experience of the Developing Economy of India and Possible Lessons $V$. S. Mahajan

19 Alternative Energy Options in Indonesia Mohammad Sadli

20 The Rural Energy Situation in China Today and Its Future Development Zheng Guanglin

Summary of the Discussion on Policy Choices in

Developing Countries

\section{PART FIVE: ENVIRONMENTAL PROBLEMS}

21 Energy Options and Environmental Considerations: the Case of Sweden Karl-Göran Mäler

22 Environmental Control Costs for Coal Energy

Technologies Edward S. Rubin

Summary of the Discussion on Environmental Problems

\section{PART SIX: CONCLUSIONS}

23 Three Views of the Conference (A) Douglas Hague,

(B) Edward Rubin and (C) Victor Urquidi 


\section{Foreword Pierre Maillet}

\section{CHAIRMAN}

The last decade has taught us two important lessons concerning energy economics and energy policy.

First, the era of world-wide concentration on one main source of energy has come to an end. After the dominance of wood, then of coal, and finally of oil, we are entering a period in which we will use a variety of sources of energy at the same time. Some are not renewable; the others renewable or very slowly exhaustible. The issue of defining the best mix of these alternative sources of energy comes to the forefront when defining an energy policy. If this problem is faced in different ways in different countries, it has to be solved in all of them, whether they are rich or poor in sources of energy.

Second, the impact of energy on the working of the national economy has become of vital importance. Surely we have known for a long time that a sufficient supply of energy is essential for the proper working of the economy, due to the ubiquitous role of this commodity. But we have realised more recently that the conditions of supply are also decisive for the functioning of the economy, through the impact on the balance of payments, on national investment and on employment, with the consequence that a good energy policy cannot be defined without taking into account very carefully the interrelations between the energy sphere and the economic sphere as a whole.

The first lesson has been learned, and most of the prospective studies about the balance between supply and demand for energy for the next few decades, either nationally or at world level, show quite clearly this process of diversification on the supply side. In addition, the possibilities of technical transformation from one primary source to many are being extensively studied in many laboratories, both private and public. 
The second lesson, on the other hand, is penetrating the ways of thinking of the decision-makers much more slowly, and this delay is at the root of many misconceptions and failures in energy policies.

For this reason, the International Economic Association decided to organise one of its annual conferences around the theme of the economics of choice between energy sources, with the hope that papers and discussions might help the vast number of people interested in energy decisions, especially at the national or supranational levels, to accelerate the process of integrating in their reasoning various aspects of the interface between energy and the economy.

The conference held in Tokyo in October 1982 gathered together people from the academic world and people with much experience of energy policy (either in administration or as politicians), coming from fourteen countries all over the world and covering a wide spectrum of problems, different experiences and types of economies: five industrialised and market-oriented economies, three centrally-planned economies, six developing countries in Latin America and Asia.

The idea of holding such a conference was first expressed by Professor Shigeto Tsuru, former President of the Association, and was immediately endorsed by the Executive Committee. To both of them I express my sincere thanks. But Professor Tsuru should also be thanked very strongly for the ceaseless support he gave, as Cochairman of the Programme Committee, for the organisation and the holding of the conference. In fact, without him this conference would never have taken place. Once more he has given distinguished service to the International Economic Association and to economic science. 


\section{Acknowledgements}

The International Economic Association wishes first to express its great appreciation of the work done in the organisation of this conference by Professor Shigeto Tsuru. Not only did he participate in its scientific preparation and ensure that all the arrangements for it went smoothly; he also arranged finance from two Japanese organisations. We thank the Federation of Electric Industries and Japan City Gas Association for their very generous financial support which completely covered all aspects of the conference - its scientific preparation, local administrative costs and travel and accommodation for all participants.

Programme Committee

$\left.\begin{array}{l}\text { Pierre Maillet } \\ \text { Shigeto Tsuru }\end{array}\right\}$ Co-chairmen

A. Adelman

Oleg Bogomolov

Joe Stanislaw

Miguel S. Wionczek 


\section{List of Contributors and Participants}

Mr N. Amaya, Adviser to the Japan Industrial Policy Research Institute, Tokyo, Japan.

Professor Lars Bergman, Stockholm School of Economics, Sweden. Professor Antonio Barros de Castro, University of Rio de Janeiro, Brazil.

Professor Istvan Dobozi, Institute for World Economy, Budapest, Hungary.

Mr Lucien Gouni, Electricité de France, Paris, France.

Professor Sir Douglas Hague, Oxford Centre for Management Studies, Oxford, UK.

Professor Gerhard Hüber, Akademie der Wissenschaften der DDR, Berlin.

Mr Toyoaki Ikuta, Institute of Energy Economics, Tokyo, Japan.

Professor V. S. Mahajan, Department of Economics, Punjab University, Chandigarh, India.

Professor Pierre Maillet, University of Lille, France.

Professor K. G. Mäler, Stockholm School of Economics, Sweden.

Professor Tasuku Noguchi, Keio University, Tokyo, Japan.

Mr Michael Posner, Social Science Research Council, London, UK.

Professor Kamta Prasad, Indian Institute of Public Administration, New Delhi, India.

Dr S. Ramesh, Ministry of Energy, New Delhi, India.

Dr Chris Rowland, Farnham, UK.

Professor E. S. Rubin, Department of Mechanical Engineering, Carnegie-Mellon University, Pittsburgh, USA.

Professor M. Sadli, Djakarta, Indonesia.

Professor Wolfgang Sassin, International Institute for Applied Systems Analysis, Laxenburg, Austria.

Professor Hans-Karl Schneider, Institut an der Universität Köln, German Federal Republic.

Dr Walter Schulz, Institut an der Universität Köln, German Federal Republic. 
Professor V. A. Shelest, Academy of Sciences, Moscow, USSR.

Professor Joe Stanislaw, International Energy Agency, Paris, France. Professor G. Szegö, University of Rome, Italy.

Professor Shigeto Tsuru, Editorial Adviser, Asahi-Shimbun, Tokyo, Japan.

Professor Victor L. Urquidi, Presidente, El Colegio de Mexico, Mexico.

Dr José Miguel Uzcategui, Presidente, Federacion de Colegios de Economistas de Venezuela, Caracas, Venezuela.

Professor M. S. Wionczek, El Colegio de Mexico, Mexico.

Professor Zheng Guanglin, Institute of Scientific and Technical Information of China, Beijing, China. 


\section{Abbreviations and Acronyms}

$\begin{array}{ll}\text { ASEAN } & \text { Association of South East Asian Nations (Indonesia, } \\ \text { atm } & \text { Malaysia, Philippines, Singapore, Thailand) } \\ \text { bbl } & \text { bandard atmosphere pressure } \\ \text { b/d } & \text { barrels a day } \\ \text { boe } & \text { barrels oil equivalent } \\ \text { BS } & \text { British Standards } \\ \text { Btu } & \text { British thermal units } \\ \text { CES } & \text { constant elasticity of substitution } \\ \text { cfd } & \text { cubic feet a day } \\ \text { CHP } & \text { combined heat and power } \\ \text { cif } & \text { cost, insurance and freight } \\ \text { cm } & \text { centimetre } \\ \text { CMEA } & \text { Council for Mutual Economic Assistance } \\ \text { CPE } & \text { centrally planned economies } \\ \text { cu } & \text { cubic } \\ \text { DC } & \text { Developing Country } \\ \text { DDR } & \text { Deutsches Demokratisches Republik } \\ \text { DH } & \text { district heating } \\ \text { EDF } & \text { Electricité de France } \\ \text { EEC } & \text { European Economic Community } \\ \text { EPA } & \text { Environmental Protection Agency (USA) } \\ \text { ESP } & \text { electrostatic precipitator } \\ \text { fob } & \text { free on board } \\ \text { G } & \text { Giga/10 } \\ \text { GDP } & \text { gross domestic product } \\ \text { GDR } & \text { German Democratic Republic } \\ \text { GNI } & \text { gross national income } \\ \text { GWh } & \text { Giga watt hours } \\ \text { ha } & \text { hectare } \\ \text { HMSO } & \text { Her Majesty's Stationery Office } \\ & \end{array}$




$\begin{array}{ll}\text { hp } & \text { horse-power } \\ \text { IEA } & \text { International Energy Agency } \\ \text { IIASA } & \text { International Institute for Applied Systems Analysis } \\ \text { ISIC } & \text { International Standard Industrial Classification } \\ \text { K } & \text { kilo } \\ \text { kcal } & \text { kilo calories } \\ \text { kW } & \text { kilowatt } \\ \text { kWh } & \text { kilowatt hours } \\ \text { LDC } & \text { less developed countries } \\ \text { LNG } & \text { liquefied natural gas } \\ \text { LPG } & \text { liquid propane gas } \\ \text { m } & \text { metre } \\ \text { M } & \text { mega/million/10 } \\ \text { M b/d } & \text { million barrels a day } \\ \text { mm } & \text { millimetre } \\ \text { Mtoe } & \text { million tons oil equivalent } \\ \text { mW } & \text { megawatt } \\ \text { NGL } & \text { natural gas liquids } \\ \text { OECD } & \text { Organisation for Economic Co-operation and Develop- } \\ & \text { ment } \\ \text { OPEC } & \text { Organisation of Petroleum Exporting Countries } \\ \text { PFBC } & \text { pressurised fluid bed combustion } \\ \text { QJE } & \text { Quarterly Journal of Economics } \\ \text { R \& D } & \text { research and development } \\ \text { SCR } & \text { selective catalytic reduction } \\ \text { SIC } & \text { Standard Industrial Classification } \\ \text { t } & \text { tons } \\ \text { T } & \text { Tera/10 } \\ \text { th } & \text { thousand } \\ \text { toe } & \text { tons oil equivalent } \\ \text { TPE } & \text { total primary energy } \\ \text { TSP } & \text { electric precipitator for particulates } \\ \text { TW } & \text { terawatt } \\ \text { TWh } & \text { terawatt hours } \\ & \end{array}$

